\title{
Reuse of waste ashes formed at oil shale based power industry in Estonia
}

\author{
R. Kuusik, M. Uibu, A. Trikkel \& T. Kaljuvee \\ Tallinn University of Technology, Estonia
}

\begin{abstract}
Estonian oil shale belongs to low-grade fossil fuels and by its combustion huge quantities of ash (currently about 5 million tons annually) are formed. Since 1959 pulverized firing (PF) has been used, and circulating fluidized bed combustion (CFBC) technology has recently been implemented - two units each of $215 \mathrm{MW}$ capacity are in operation. In previous investigations of PF ashes the results have been used as a basis for several large-scale applications like production of construction materials and conditioning/neutralizing of soils; a developing of industrial applications for CFBC ashes is hindered by insufficient basic data. In the current investigation attention was focused on the reactivity of ashes towards $\mathrm{SO}_{2}$ and $\mathrm{CO}_{2}$ in heterogeneous gas - solid and gas - water - solid systems, being important for characterization of ashes as sorbents for the capture of acidic gases named from flue gases. The significant differences in chemical and phase composition as well as in surface properties of ashes have been shown. The $\mathrm{SO}_{2}$-binding characteristics for CFBC ashes are higher than for $\mathrm{PF}$ ashes and they have more perspective as dry sorbents of sulphur dioxide. Also, under wet carbonization conditions, CFBC ashes can be carbonized more deeply as compared to PF ashes. As a result of carbonation, ashes could be environmentally friendly landfilled and abatement of $\mathrm{CO}_{2}$ emissions will be achieved.
\end{abstract}

Keywords: Estonian oil shale, pulverized firing, circulating fluidized bed combustion, waste ashes, reactivity, sulphur dioxide, carbon dioxide.

\section{Introduction}

Estonian power supply is over $90 \%$ covered by oil shale fired thermal power plants. Local solid fossil fuel oil shale is characterized by low heating value 
(8.3-8.5 MJ/kg), moderate moisture content (10-13\%), high content of minerals $(60-65 \%)$ and by the unique and complicated chemical and mineralogical composition of last one. Mineral matter of the Estonian oil shale consists mainly of two components: carbonate matter and sandy-clay matter [1]. In the course of combustion, fuel inorganic part undergoes several chemical transformations, from decomposition processes to the formation of new secondary mineral compounds and phases at higher temperatures.

The mechanism of the processes that take place during pulverized firing (PF) of oil shale, including the formation of ash deposits at heat-transfer surfaces, is thoroughly examined by Ots [1], Ots et al. [2]. Investigations of fly ash composition and reactivity brought about developing and introducing ashrecycling processes like production of various building materials, cement with special properties and other products (Kikas [3]). Ash is also utilized as an expedient material in road construction as well as soil conditioner in agriculture (Kärblane [4]) and as a neutralizing additive in the production of mineral fertilizers (Veiderma et al. [5]). In addition, it could be used as a $\mathrm{SO}_{2}$ and $\mathrm{CO}_{2}$ sorbent (Trikkel [6], Kuusik et al. [7]).

Compared to PF, in the case of circulating fluidized-bed combustion (CFBC) the operating temperatures are considerably lower. Consequently, chemical and phase composition of CFBC waste ashes differ noticeably (Kuusik et al. [8]) and that is why the differences in chemical reactivity can also be expected.

The aim of the current study was to elucidate chemical reactivity of CFBC ashes compared to PF ones in the systems that are important in the formation of ash deposits in a boiler, at ash deposition at landfill, at flue gas desulphurization as well as at reducing $\mathrm{CO}_{2}$ emissions.

\section{Materials and methods}

Ash samples used were collected from different points of the ash-separation systems of CFBC and PF boilers at the Estonian Thermal Power Plant. The CFBC ashes studied were bottom ash (CFBC/BA), intrex ash (CFBC/INT), economizer ash (CFBC/ECO), air preheater ash (CFBC/PHA), electrostatic precipitator ash from fields 1 and 4 (CFBC/ESPA 1 and 4) and mixture of ashes (CFBC/Mix) taken from a common ash silo where the ash from different units is collected before landfilling on ash fields. The $\mathrm{PF}$ ashes used were bottom ash (PF/BA), superheater ash (PF/SHA), economizer ash (PF/ECO), cyclone ash $(\mathrm{PF} / \mathrm{CA})$ and electrostatic precipitator ash from fields 1 and 3 (PF/ESPA 1 and 3). Chemical and phase composition as well as physical properties of these ashes are presented in Table 1 and discussed in more detail in paper of Kuusik et al. [8].

Reactivity of ashes towards $\mathrm{SO}_{2}$ or $\mathrm{CO}_{2}$ was tested in a heterogeneous gassolid system using thermogravimetric equipment (Q-derivatograph, MOM) under isothermal conditions. In both cases the temperature of the isothermal experiment was $700^{\circ} \mathrm{C}$, partial pressure of $\mathrm{SO}_{2}$ or $\mathrm{CO}_{2}$ was 190 and $144 \mathrm{~mm} \mathrm{Hg}$, respectively. The samples $(100 \pm 0.5 \mathrm{mg})$ were heated up to $700^{\circ} \mathrm{C}$ in air with heating rate of $10 \mathrm{~K} / \mathrm{min}$. The gas mixture was then fed into the furnace with the 
rate of $270 \mathrm{ml} / \mathrm{min}$. The thickness of the sample layer in multiplate Pt crucibles was about $0.2-0.3 \mathrm{~mm}$. To study the effect of grinding on $\mathrm{SO}_{2}-$ and $\mathrm{CO}_{2}$-binding, the initial samples (except for $\mathrm{CFBC} / \mathrm{BA}$, which was slightly crushed to pass the $630 \mu \mathrm{m}$ sieve) and the ground ones were used. Samples were ground in a oneball vibration mill until the majority (approx. 85-100\%) passed through the $45 \mu \mathrm{m}$ sieve. In some experiments with $\mathrm{CO}_{2}$, samples were heated up to $900^{\circ} \mathrm{C}$ to achieve full decomposition of carbonates and then cooled to $700^{\circ} \mathrm{C}$ to perform isothermal binding.

To characterize high-temperature binding of $\mathrm{SO}_{2}$ and $\mathrm{CO}_{2}$ by ashes, the following parameters were calculated:

$\mathrm{SO}_{2}$ - or $\mathrm{CO}_{2}$-binding capacity $\left(B C\right.$; weight of $\mathrm{SO}_{2}$ or $\mathrm{CO}_{2}$ bound by $100 \mathrm{mg}$ of sample),

$\mathrm{SO}_{2}$ - or $\mathrm{CO}_{2}$-binding rate $\left(W ; \mathrm{mg} \mathrm{SO}_{2}\right.$ or $\mathrm{CO}_{2}$ per $\mathrm{mg}$ sample $\cdot \mathrm{min}^{-1}$ ),

$\mathrm{SO}_{2}$ - or $\mathrm{CO}_{2}$-binding efficiency, $(\mathrm{BE}, \%)$ showing the extent of utilization of $\mathrm{CaO}$ and $\mathrm{MgO}$ contained in the sample

The parameters were calculated on the basis of experimental and analyses data and the following summary binding reactions:

$$
\begin{gathered}
\mathrm{CaO}(\mathrm{s})+\mathrm{CO}_{2}(\mathrm{~g}) \rightarrow \mathrm{CaCO}_{3}(\mathrm{~s}) \\
\mathrm{CaO}(\mathrm{s})+\mathrm{SO}_{2}(\mathrm{~g})+1 / 2 \mathrm{O}_{2}(g) \rightarrow \mathrm{CaSO}_{4}(\mathrm{~s}) \\
\mathrm{MgO}(\mathrm{s})+\mathrm{SO}_{2}(\mathrm{~g})+1 / 2 \mathrm{O}_{2}(g) \rightarrow \mathrm{MgSO}_{4}(\mathrm{~s})
\end{gathered}
$$

\begin{tabular}{|c|c|c|c|c|c|c|c|c|c|}
\hline \multirow{2}{*}{$\mathrm{ASH}$} & \multicolumn{7}{|c|}{ Content $(\%)$} & \multirow{2}{*}{$\begin{array}{c}d_{\text {mean }} \\
\mu \mathrm{m}\end{array}$} & \multirow{2}{*}{$\begin{array}{l}\text { SSA } \\
\mathrm{m}^{2} / \mathrm{g}\end{array}$} \\
\hline & $\mathrm{CaO}_{\mathrm{t}}$ & $\mathrm{CaO}_{\mathrm{f}}$ & $\mathrm{MgO}_{\mathrm{t}}$ & $\mathrm{CO}_{2}$ & $\mathrm{~S}_{\mathrm{t}}$ & $\mathrm{S}_{\text {sulfitic }}$ & $\mathrm{S}_{\text {sulfidid }}$ & & \\
\hline $\mathrm{CFBC} / \mathrm{BA}$ & 49.39 & 12.48 & 9.25 & 15.14 & 4.53 & 4.32 & 0.10 & 197 & 2.06 \\
\hline $\mathrm{CFBC/INT}$ & 47.59 & 18.87 & 13.65 & 1.23 & 7.76 & 7.70 & 0.02 & 95 & 2.61 \\
\hline CFBC/ECO & 32.84 & 10.40 & 9.50 & 5.48 & 2.32 & 2.22 & 0 & 27 & 6.89 \\
\hline CFBC/PHA & 35.17 & 12.26 & 10.77 & 4.30 & 3.31 & 3.27 & 0.0013 & 32 & 5.40 \\
\hline CFBC/ESPA1 & 29.52 & 8.45 & 8.33 & 4.60 & 1.71 & 1.71 & 0 & 25 & 8.00 \\
\hline CFBC/ESPA4 & 28.88 & 2.82 & 9.35 & 3.80 & 2.23 & 2.21 & 0 & 23 & 7.92 \\
\hline CFBC/Mix & 33.28 & 10.33 & 9.50 & 6.41 & 2.46 & 2.43 & 0.03 & 28 & 7.11 \\
\hline $\mathrm{PF} / \mathrm{BA}$ & 50.75 & 24.84 & 15.19 & 2.75 & 1.27 & 1.27 & 0 & 115 & 1.75 \\
\hline PF/SHA & 54.71 & 23.08 & 7.81 & 0.96 & 1.98 & 1.93 & 0 & 105 & 0.50 \\
\hline $\mathrm{PF} / \mathrm{ECO}$ & 48.00 & 16.04 & 8.24 & 2.50 & 2.52 & 2.52 & 0.006 & 53 & 0.44 \\
\hline $\mathrm{PF} / \mathrm{CA}$ & 49.39 & 22.52 & 14.19 & 0.70 & 1.33 & 1.33 & 0 & 48 & 0.36 \\
\hline PF/ESPA1 & 36.08 & 13.56 & 11.26 & 1.16 & 2.74 & 2.74 & 0 & 24 & 0.61 \\
\hline PF/ESPA3 & 26.85 & 5.98 & 5.98 & 0.80 & 3.67 & 3.67 & 0 & 23 & 1.09 \\
\hline
\end{tabular}

Table 1: Chemical composition and physical properties of CFBC and PF ashes.

Carbonization of aqueous suspensions of ash with model gas, whose composition (10\% $\mathrm{CO}_{2}$ and $90 \%$ air) simulated $\mathrm{CO}_{2}$ content of flue gases formed 
at oil shale combustion, was carried out in an absorber (diameter $55 \mathrm{~mm}$, water column height $500 \mathrm{~mm}$ ) equipped with magnetic stirrer for achieving a better interfacial contact and a sintered glass gas distributor (pore diameter $100 \mu \mathrm{m}$ ). The experiment was carried out until suspension $\mathrm{pH}$ reached 7.5. Then the suspension was filtered and solid residue dehumidified at $105^{\circ} \mathrm{C}$. For the liquid phase, $\mathrm{Ca}^{2+}$ content (Vilbok [9]), TDS (total dissolved solids) and alkalinity [10] were determined. For the solid residue the content of free $\mathrm{CaO}$ (Reispere [11]) and $\mathrm{CO}_{2}$ and $\mathrm{pH}$ of aqueous suspension of solid residue [12] were determined.

\section{Results and discussion}

Free $\mathrm{CaO}$ is the main binder of $\mathrm{SO}_{2}$ and $\mathrm{CO}_{2}$ in the ashes (Reactions 1 and 2). Although $\mathrm{MgO}$ does not take part in $\mathrm{CO}_{2}$ binding under these conditions [13], it has a certain role in $\mathrm{SO}_{2}$ binding (Kaljuvee et al. $[13,14]$ ). Hence, the negative influence of coarser fractional composition of the samples and, correspondingly, the lower level of specific surface area (SSA) in the case of, for example, CFBC/BA (mean particle size $197 \mu \mathrm{m}$; SSA $2.1 \mathrm{~m}^{2} / \mathrm{g}$ ) and CFBC/INT (95 $\mu \mathrm{m}$; $2.6 \mathrm{~m}^{2} / \mathrm{g}$ ) should be compensated by higher level of free $\mathrm{CaO}$ content -11.9 and $18.9 \%$, respectively (see Table 1 ).

$\mathrm{PF} / \mathrm{BA}$ and $\mathrm{PF} / \mathrm{CA}$ are both characterized by a quite high content of free $\mathrm{CaO}$ (23-25\%), but they differ noticeably (5 times) in their SSA. PF/ESPA1 is characterized by fine fractional composition $\left(d_{\text {mean }}=24 \mu \mathrm{m}\right)$, low content of free $\mathrm{CaO}$, and despite a small particle size by a low value of SSA $\left(0.61 \mathrm{~m}^{2} / \mathrm{g}\right)$ and should show a modest binding activity. $\mathrm{CFBC} / \mathrm{ECO}$ and $\mathrm{CFBC} / \mathrm{PHA}$ are somewhere in the middle of the scale considering these parameters.

\subsection{Transformations in the Gas-Solid System $\mathrm{SO}_{2}$-Ash}

After 30 minutes of the contact between solid and gaseous phases, $\mathrm{SO}_{2}$-binding capacity of different CFBC ashes was about 26-30 mg $\mathrm{SO}_{2}$ per $100 \mathrm{mg}$ sample. $55-70 \%$ of this value was achieved during the first 2-min contact already (Fig. 1).

$B C$ values for PF ashes differed from each other more considerably - from 10.4 to $23.1 \mathrm{mg} \mathrm{SO}$ per $100 \mathrm{mg}$ sample - being the highest for PF/ESPA1. During a 2-min contact, PF/BA bound 58\%, while PF/ESPA1 and PF/CA only $33 \%$ of the total amount of bound sulphur dioxide. This data correspond to the data obtained in our earlier research (Kaljuvee et al. [13, 14]) and can be explained by the differences in chemical and fractional composition as well as in physical and chemical properties of the ashes. Thus, CFBC/BA and CFBC/INT have coarser fractional composition and lower SSA level, but higher free $\mathrm{CaO}$ content, while CFBC/ESPA has fine fractional composition (and high level of SSA), but low content of free $\mathrm{CaO}$ (see Table 1). Differences in $B C$ values for $\mathrm{PF} / \mathrm{BA}$ and $\mathrm{PF} / \mathrm{CA}$ can be explained by their different SSA values (1.75 and $0.36 \mathrm{~m}^{2} / \mathrm{g}$, respectively). 

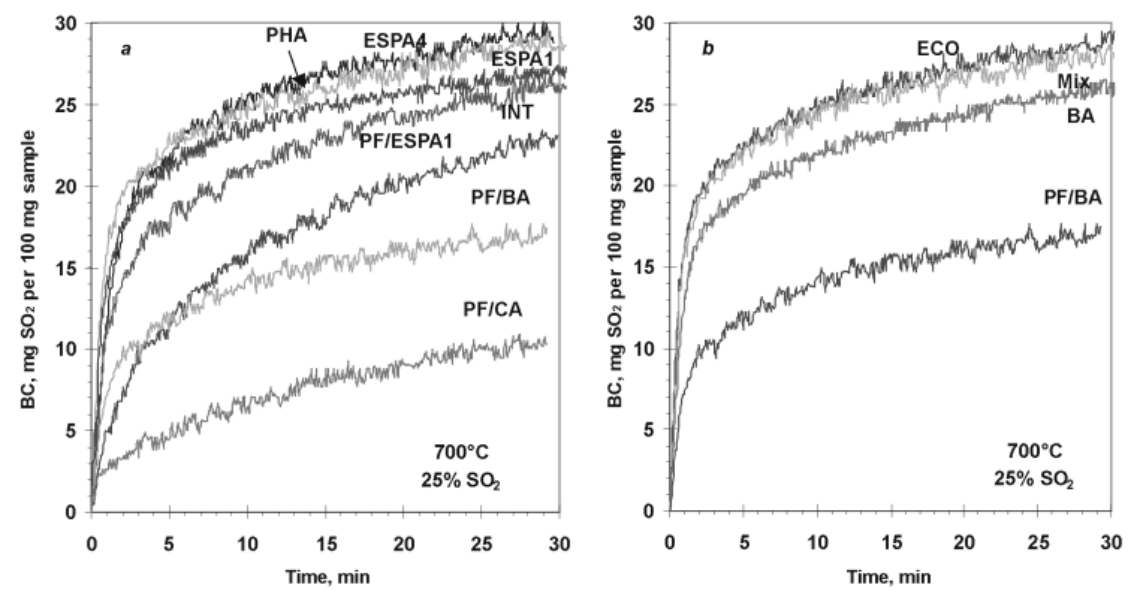

Figure 1: $\quad \mathrm{SO}_{2}$-binding capacity $(B C)$ of the ashes.

In the experiments of $\mathrm{SO}_{2}$-binding $\mathrm{MgO}$, free $\mathrm{CaO}$ and, partially, Ca-silicates can take part in the reactions with $\mathrm{SO}_{2}$. So, in this case binding efficiency, $B E$ was calculated on the basis of total content of $\mathrm{CaO}$ and $\mathrm{MgO}$ in the sample $\mathrm{BE}(\mathrm{CaO} \cdot \mathrm{MgO}) . \mathrm{BE}(\mathrm{CaO} \cdot \mathrm{MgO})$ values indicated the highest level of utilization of both oxides for ESPA4 (74\%) and the lowest for BA and INT - about $41 \%$ (Fig. 2) BA was the most active among $\mathrm{PF}$ ashes, having an average $\mathrm{SO}_{2}$-binding rate $0.10 \mathrm{mg} \mathrm{SO}_{2}$ per $\mathrm{mg}$ sample $\cdot \mathrm{min}^{-1}$. Like other indicators of $\mathrm{SO}_{2}$-binding ability, the values of $\mathrm{BE}(\mathrm{CaO} \cdot \mathrm{MgO})$ for PF ashes were much less than those for CFBC ashes: $46.9 \%$ (the highest) for ESPA1, $25.7 \%$ for BA and $15.4 \%$ for CA (Fig. 2).

For all the ashes studied preliminary grinding (up to grain size $-45 \mu \mathrm{m}$ ) increased their binding ability. In general, it was noticed that for the ashes characterized by coarse fractional composition (CFBC/BA, CFBC/INT, PF/BA) and/or those having been allocated to high temperatures at $\mathrm{PF}$ (especially $\mathrm{PF} / \mathrm{CA}$ ) resulting in the formation of liquid phases hindering further diffusion of $\mathrm{SO}_{2}$ into the particles.

Thus, grinding increased the $B C$ and $B E$ values for $\mathrm{PF} / \mathrm{CA} 2.2$ times, for $\mathrm{CFBC} / \mathrm{BA}, \mathrm{CFBC} / \mathrm{INT}$ and $\mathrm{PF} / \mathrm{BA} 55-70 \%$, for $\mathrm{CFBC} / \mathrm{ECO}$ and $\mathrm{CFBC} / \mathrm{PHA}$ 20-30\%, for CFBC/ESPA1 and PF/ESPA1 10-20\%, and for CFBC/ESPA4 there was no change in these values. Among ground $C F B C$ ashes, $B C$ value was the highest for BA and INT (40-42 mg $\mathrm{SO}_{2}$ per $100 \mathrm{mg}$ sample), $B E$ value for ECO $-81.5 \%$ (Fig. 2). Among PF ashes, $B C$ value was the highest for BA $-30.2 \mathrm{mg}$ $\mathrm{SO}_{2}$ per $100 \mathrm{mg}$ sample and $B E$ value for ESPA1 $-50.6 \%$ (see Fig. 2).

These results are in good correlation with the increase in the SSA of the samples: for $\mathrm{PF} / \mathrm{CA} 4.4$ times (from $0.36 \mathrm{~m}^{2} / \mathrm{g}$ to $1.45 \mathrm{~m}^{2} / \mathrm{g}$ ), for $\mathrm{CFBC} / \mathrm{BA}$, CFBC/INT, and PF/BA 1.5-2.3 times, for the other ashes on the level of 1.1 times, except for CFBC/ESPA4 and PF/ESPA1, for which even a small decrease in the SSA was observed. Comparing these results with those obtained with 
Karinu limestone, the $B C$ values of the more active ashes (CFBC/BA and INT) were only 1.4 times less, but the $B E$ value of $\mathrm{CFBC} / \mathrm{ECO}$ was on the same level than that of Karinu limestone (see Fig. 2).

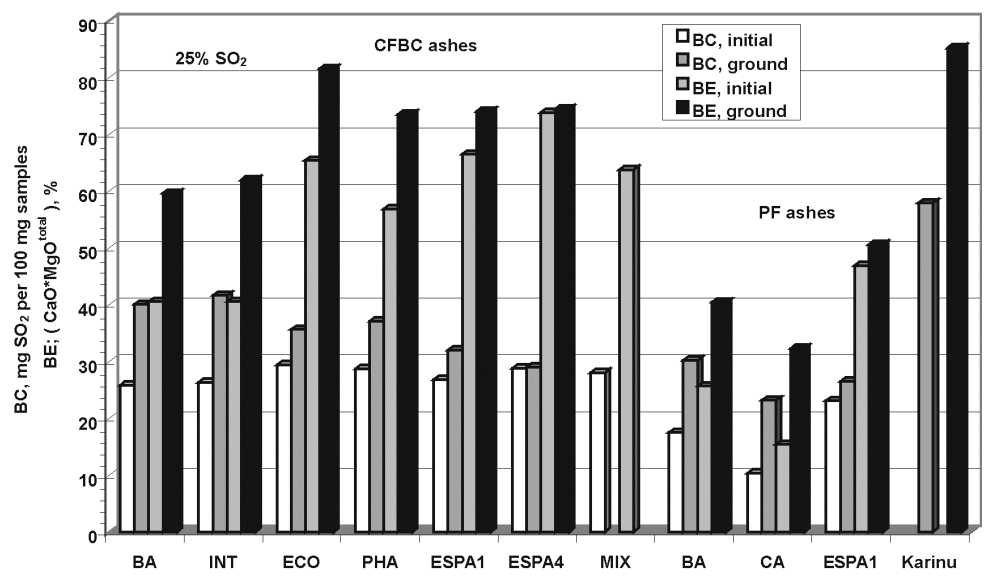

Figure 2: The influence of grinding on $\mathrm{SO}_{2}$-binding capacity $(B C)$ and efficiency $(\mathrm{BE} / \mathrm{CaO} \cdot \mathrm{MgO})$ at $700^{\circ} \mathrm{C}$ after 30 -min contact.

\subsection{Transformations in the gas-solid system $\mathrm{CO}_{2}-\mathrm{ash}$}

$\mathrm{CO}_{2}$-binding capacities of the ashes stay between 1 and $13 \mathrm{mg} \mathrm{CO}_{2} / 100 \mathrm{mg}$ (Fig. 3). Among CFBC samples, the highest binding capacity was calculated for bottom ash. Binding capacities of ECO, PHA and Mix were about $5 \mathrm{mg}$ $\mathrm{CO}_{2} / 100 \mathrm{mg}$, the lowest $B C$ values were of INT and ESPA. Bottom ash of pulverized firing bound also about $5 \mathrm{mg}$ of $\mathrm{CO}_{2}$ per $100 \mathrm{mg}$ sample; binding capacities of PF/CA and PF/ESPA were low.

Grinding of CFBC samples decreased their binding capacities noticeably, except for INT. Decrease in $B C$ was from $12 \%$ (BA) to $60-70 \%$ (ECO, PHA and ESPA). This phenomenon is specific of CFBC samples, because $B C$ of ground $\mathrm{PF}$ samples is about $75-85 \%$ higher as compared to the initial ones. This correlates with the increase in specific surface area, which is 4 times higher for ground $\mathrm{PF} / \mathrm{CA}$ and 1.5 times higher for ground $\mathrm{PF} / \mathrm{BA}$. However, grinding increased also SSA of CFBC ashes. The decrease in $B C$ was less for BA and INT, also the increase in SSA during grinding was higher for these samples -2.3 and 1.6 times, respectively.

The effect of decarbonization temperature on $B C$ was even more severe - the decrease in $B C$ for the samples heated before binding to $700^{\circ} \mathrm{C}$ and $900^{\circ} \mathrm{C}$ was $67 \%$ - from 5.5 to $1.8 \mathrm{mg} \mathrm{CO} / 100 \mathrm{mg}$. 
Separate experiments were performed to estimate changes in SSA and $\mathrm{CaO}_{\mathrm{f}}$ content during pre-treatment. It was found that a 30-min grinding increased SSA from 5.3 to $7.7 \mathrm{~m}^{2} / \mathrm{g}$, but heating of this ground sample to $900^{\circ} \mathrm{C}$ decreased its SSA to $3.1 \mathrm{~m}^{2} / \mathrm{g}$. Also the level of free $\mathrm{CaO}$ decreased remarkably during heating. Presumably, some secondary reactions take place during heating that reduce free $\mathrm{CaO}$ content in $\mathrm{CFBC}$ ashes being more intensive at higher temperatures.

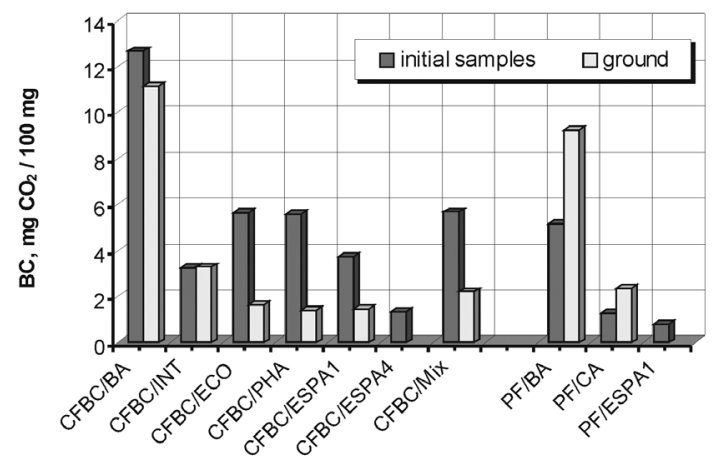

Figure 3: $\quad \mathrm{CO}_{2}$-binding capacities $(\mathrm{BC})$ of the initial and ground to particle size less than $45 \mu \mathrm{m}$ ash samples after 30 -min binding.

Thus, as compared to PF ashes, $\mathrm{CO}_{2}$ binding capacities of $\mathrm{CFBC}$ ashes are 23 times higher. The best results were obtained in both cases with bottom ashes. The method of grinding used improved noticeably binding parameters of PF ashes and reduced those of CFBC ashes. According to the results obtained, it can also be concluded that intensive contamination of heating surfaces in CFB boilers with secondary carbonaceous deposits should not be a serious problem.

\section{3 $\mathrm{CO}_{2}$-Ash-Water System}

To characterize $\mathrm{CO}_{2}$-binding in ash-water suspensions the following parameters were used. Carbonization extent was described by index $N$ indicating the excess of the $\mathrm{CO}_{2}$ amount entrained into suspensions over the stoichiometric ratio calculated according to Equation (1). Effectiveness of the carbonization process was described by the $\mathrm{CO}_{2}$-binding degree $\left(\mathrm{BD}_{\mathrm{CO} 2}\right) . B \mathrm{BD}_{\mathrm{CO}}$ shows which part of the theoretical ash-binding capacity is utilized. It was calculated basing on the changes in $\mathrm{CO}_{2}$ content:

$$
\mathrm{BD}_{\mathrm{CO} 2}=\frac{\mathrm{CO}_{2}}{\mathrm{CO}_{2 \max }} \cdot 100 \%
$$

$\mathrm{CO}_{2}$ is analytically determined $\mathrm{CO}_{2}$ content of the sample (\%)

$\mathrm{CO}_{2 \max }$ is the maximal possible $\mathrm{CO}_{2}$ content of the sample (\%), calculated on the basis of content of free or total $\mathrm{CaO}$ in the initial sample as follows: 


$$
\mathrm{CO}_{2 \max }=\frac{\mathrm{CaO}^{i} \cdot \mathrm{M}_{\mathrm{CO}_{2}} / \mathrm{M}_{\mathrm{CaO}}+\mathrm{CO}_{2}^{i}}{100+\mathrm{CaO}^{i} \cdot \mathrm{M}_{\mathrm{CO}_{2}} / \mathrm{M}_{\mathrm{CaO}}} \cdot 100 \%
$$

$\mathrm{CaO}^{i}$ and $\mathrm{CO}_{2}{ }^{i}$ denote the content (\%) of free or total $\mathrm{CaO}$ and $\mathrm{CO}_{2}$ in the initial sample, respectively.

The results obtained are presented in Figure 4. Chemical analysis of the liquid phase indicated that after carbonization the suspensions of both kinds of ashes contain small amounts of alkaline components. In the suspensions of CFBC ashes, content of $\mathrm{Ca}^{2+}$ ion is near saturation point or even higher (in the case of intrex ash $1110 \mathrm{mg} / \mathrm{l}$ ). In the suspensions of PF ashes, the concentrations of $\mathrm{Ca}^{2+}$ ions stay on a noticeably lower level $(240-590 \mathrm{mg} / \mathrm{l})$. The TDS values were proportional to the content of $\mathrm{Ca}^{2+}$ ion.
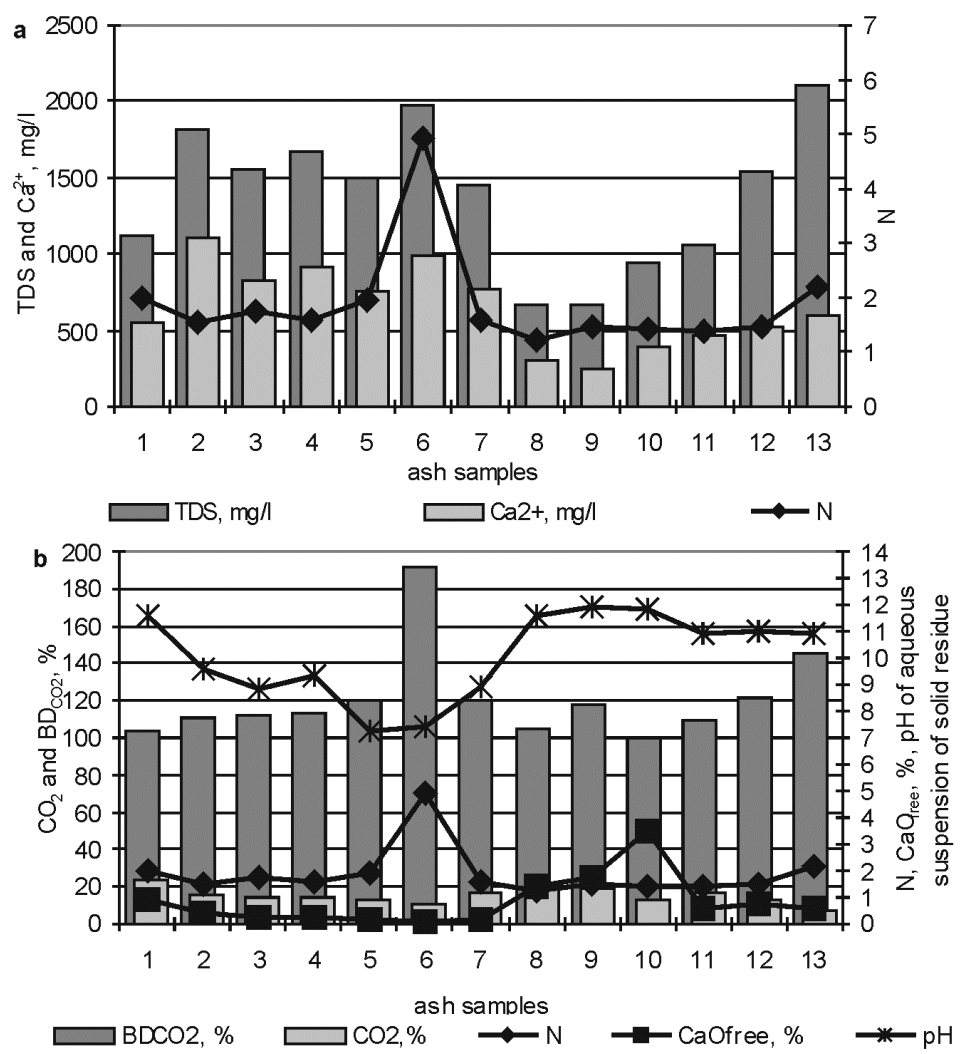

Figure 4: $\mathrm{Ca}^{2+}$ and TDS contents in suspensions of CFBC and PF ashes (a) and characteristics of carbonation process and its final product for $\mathrm{CFBC}$ and PF ashes (b): 1-CFBC/BA, 2- CFBC/INT, 3CFBC/ECO, 4- CFBC/PHA, 5- CFBC/ESPA1, 6-CFBC/ESPA4, 7CFBC/Mix, 8- PF/BA, 9- PF/SHA, 10- PF/ECO, 11- PF/CA, 12PF/ESPA1, 13- PF/ESPA3. 
Compared to PF ashes, CFBC ashes can be carbonized more deeply accompanied by lowering of $\mathrm{pH}$ of the solid residue in most cases below 9 (with the exception of CFBC/BA, full carbonization of which is inhibited due to coarse fractional composition. Higher $\mathrm{pH}$ value (10.9-11.9) is elicited by higher content of free $\mathrm{CaO}(0.57-3.47 \%)$ in solid residues of carbonized PF ashes. Apparently, in the case of nonporous $\mathrm{PF}$ ashes, some part of free $\mathrm{CaO}$ present is not accessible and therefore cannot take part in reaction under these conditions. The content of $\mathrm{CO}_{2}$ is proportional to that of free $\mathrm{CaO}$ and $\mathrm{CO}_{2}$ in the initial samples (see Table 1). Binding degrees that were calculated basing on content of free $\mathrm{CaO}$ in the initial samples were in CFBC and PF ashes predominantly over $100 \%$ (104.1-191.3\% and 99.9-145.1\%, respectively) because there can be other $\mathrm{CO}_{2}$ binding compounds ( $\mathrm{MgO}, \mathrm{Ca}$-silicates) present in oil shale ash of heterogeneous composition. In general, for total utilization of free $\mathrm{CaO}$ the $\mathrm{CFBC}$ ashes need less $\mathrm{CO}_{2}$ per ton of ash as they contain less free $\mathrm{CaO}$ in the initial ash.

\section{Conclusions}

1) Oil shale ashes formed in boilers operating at different combustion technologies differ by their chemical reactivity towards acidic gases.

2) Sulphation of ashes in model conditions shows that $\mathrm{SO}_{2}$-binding capacity of $\mathrm{CFBC}$ ashes at $700^{\circ} \mathrm{C}$ remained within a narrow range being the highest for $\mathrm{PF} / \mathrm{BA}$. $\mathrm{SO}_{2}$-binding capacity of $\mathrm{CFBC}$ as well as of PF ashes is not completely utilized. Being characterized by a higher binding rate during the initial stage of gas-solid contact, $\mathrm{CFBC}$ ashes could be more promising as potential $\mathrm{SO}_{2}$ sorbents for dry desulphurization of flue gases.

3) Transformations in the gas-solid system $\mathrm{CO}_{2}-\mathrm{ash}$, which are important in evaluating possibilities for formation of calcareous precipitations on heat transfer surfaces in boilers, were investigated. $\mathrm{CO}_{2}$-binding ability of the ashes at $700^{\circ} \mathrm{C}$ was relatively low, being 2-3 times higher for CFBC ashes. Within 30 minutes $8-52 \%$ of free $\mathrm{CaO}$ present in the sample was utilized. According to these data, intensive formation of secondary carbonaceous precipitations on the heat transfer surfaces of the CFB boiler is not foreseen.

4) The results of the experiments on binding gaseous $\mathrm{CO}_{2}$ by ash-water suspension indicated that, in the same conditions, CFBC ashes could be carbonized more intensively and deeply than PF ashes. Besides lime as a compound of the highest reactivity towards $\mathrm{CO}_{2}$ also other components like $\mathrm{MgO}$ and $\mathrm{Ca}$-silicates present in ash take part in $\mathrm{CO}_{2}$-binding reactions. Owing to improved $\mathrm{CO}_{2}$-binding rate, more intensive natural $\mathrm{CO}_{2}$-mineralization of CFBC ashes as compared to PF ashes in open-air deposits as well as intensive binding of $\mathrm{CO}_{2}$ from flue gases by aqueous suspension of ash are expected.

\section{Acknowledgements}

Authors express their gratitude to Estonian Science Foundation (Grant 6195), SC Narva Elektrijaamad and Nordic Energy Research Programme (Project "Nordic $\mathrm{CO}_{2}$ sequestration") for partial funding of this work. 


\section{References}

[1] Ots, A. Oil Shale Combustion Technology: Tallinn. 768 pp. 2004. [in Estonian]

[2] Ots, A., Arro, H., Jovanovic, L. et al. The Behaviour of Inorganic Matter of Solid Fuels during Combustion. Fouling and Corrosion in Steam Boilers: Beograd, 276 pp, 1980.

[3] Kikas, V. Composition and binder properties of Estonian kukersite oil shale ash. International Cement-Lime-Gypsum, 50(2), pp. 112-126, 1997.

[4] Kärblane, H. Handbook of Plant Nutrition and Fertilization. Ministry of Agriculture of the Republic of Estonia: Tallinn. 285 pp. 1996. [in Estonian]

[5] Certificate of Authorship 280493 (USSR). Method of Neutralization of Phosphoric Acid.Tallinn Technical University. Veiderma, M. A., Vendelin, A. G., Kuusik, R. O., Kuusk, A. A.-M. Appl. 30.12.1968, No.1293097/23-26. Publ. in B. I., 1970 No.28. MKI C 05b 1/02. [in Russian]

[6] Trikkel, A. Estonian Calcareous Rocks and Oil Shale Ash as Sorbents for $\mathrm{SO}_{2} /$ Academic Dissertation, Tallinn University of Technology: TTU Press, 70 pp, 2001.

[7] Kuusik, R., Veskimäe, H., Uibu M. Carbon Dioxide Binding in the Heterogeneous Systems Formed by Combustion of Oil Shale. Transformations in the system suspension of ash - flue gases. Oil Shale, 19(3), pp. 277-288, 2002.

[8] Kuusik, R., Uibu, M, Kirsimäe, K. Composition and physico-chemical characterization of oil shale ashes formed at industrial scale boilers with CFBC. Oil Shale, 22(4S), pp. 407-419, 2005.

[9] Vilbok, H., Ott, R. Volumetric Analysis. Instructions for Practical Works / Tallinn Polytechnical Institute. - Tallinn, 1977. [in Estonian]

[10] Water Quality. Determination of Alkalinity. International standard ISO 9963-1:1994(E).

[11] Reispere, H. J. Determination of Free $\mathrm{CaO}$ Content in Oil Shale Ash / Tallinn Polytechnical Institute: Tallinn, No 245. pp. 73-76, 1996 [in Estonian]

[12] Determination of the $\mathrm{pH}$ value. Regulation (EC) No 2003/2003 of the European Parliament and of the Council of October 13, 2003 relating to fertilisers / Official Journal of the European Union. pp 60-61. 2003.

[13] Kaljuvee, T., Trikkel, A., Kuusik, R. Decarbonization of natural limecontaining materials and reactivity of calcined products towards $\mathrm{SO}_{2}$ and $\mathrm{CO}_{2}$. J. Therm. Anal. Cal, 64, pp. 1229-1240, 2001.

[14] Kaljuvee, T., Kuusik, R., Trikkel, A., Bender, V. The role of $\mathrm{MgO}$ in the binding of $\mathrm{SO}_{2}$ by lime-containing sorbents. J. Therm. Anal. Cal, 80, pp. 591-597, 2005. 